\title{
One hundred years of RGA in Grenoble
}

Mountain areas on the podium

\section{Dominique Baud}

\section{(2) OpenEdition}

Journals

Édition électronique

URL : https://journals.openedition.org/rga/2253

DOI : 10.4000/rga.2253

ISSN : $1760-7426$

Cet article est une traduction de :

Cent ans de Revue de géographie alpine à Grenoble - URL : https://journals.openedition.org/rga/2251 $[\mathrm{fr}]$

Éditeur :

Association pour la diffusion de la recherche alpine, UGA Éditions/Université Grenoble Alpes

Référence électronique

Dominique Baud, "One hundred years of RGA in Grenoble », Journal of Alpine Research / Revue de géographie alpine [En ligne], 101-3 | 2013, mis en ligne le 10 avril 2014, consulté le 08 décembre 2022. URL : http://journals.openedition.org/rga/2253 ; DOI : https://doi.org/10.4000/rga.2253

Ce document a été généré automatiquement le 8 décembre 2022.

\section{c) (i) $९$}

Creative Commons - Attribution - Pas d'Utilisation Commerciale - Pas de Modification 4.0 International - CC BY-NC-ND 4.0

https://creativecommons.org/licenses/by-nc-nd/4.0/ 


\title{
One hundred years of $R G A$ in Grenoble
}

\author{
Mountain areas on the podium
}

Dominique Baud

1 To celebrate its 100 years of existence, the Journal of Alpine Research | Revue de géographie alpine (Jar | Rga) is working to ensure the future of alpine research, for which this special issue endeavours to provide a showcase. In the spring of 2013, the journal proposed a competition with a view to promoting the results obtained by young researchers working on alpine mountain issues. More specifically, the competition's aim was to identify a few new research paths, without suggesting any particular thematic orientation, and to help these younger colleagues towards achieving their first international publication. Today, the journal is able to bring you these innovative articles dealing with a subject that it has long cherished, the mountains. The journal is thus renewing a tradition, whose roots go back a century, by publishing original articles concerning territorial and environmental issues affecting the Alpine Arc and the mountains of Europe.

2 The first aim of the journal, created in 1913 by the geographer, Raoul Blanchard, was to publish articles by students at Grenoble's Institut de Géographie Alpine. From the 1950s, it turned towards a more international public, publishing more thematic studies. Later, under the impetus of a new editorial team led by Paul and Germaine Veyret, the journal focused increasingly on the entire Alpine arc area, gradually shifting from a dominantly monographic descriptive geography to one that addressed more social questions. Articles on the geography of activities and societies assumed a more preponderant role and aspects of physical geography were examined through the prism of environmental problems (with the notion of vulnerability in particular).

3 From 1968, the journal was managed by the Association de géographie alpine (which in 2004 became the Association pour la diffusion de la recherche alpine - ADRA), linked to the Institut de Géographie Alpine and part of the Université Joseph Fourrier (Grenoble). The RGA continues to give priority to studies on the Alps but also other mountain areas of the world. In the 1980s, its review committee, which was already international, was 
further enhanced by the addition of specialists from neighbouring disciplines. The journal's scientific quality is recognized internationally and its readership extends to some fifty countries.

4 On entering the $21^{\text {st }}$ century, the RGA began to systematically translate its articles into English with the aim of reaching a wider audience, and at the same time took on a French/English mantle: Revue de géographie alpine/Journal of Alpine research. In this context of increasingly demanding scientific publications, the journal adopted the peerreview system, a guarantee of quality in the selection of both the texts and the reviewers. Following on from this, the journal became fully digital thanks to the platform 'revues.org', making articles henceforth freely accessible to everyone. However, a special annual issue containing all the texts published during the year is available in hard copy.

5 To mark its centenary, and in keeping with its commitment to reach as wide a readership as possible, the articles will now be published in two different languages: English and one of the alpine languages (French, Italian, or German) or Spanish. This decision was reached following long discussions within the editorial committee and was also the subject of a certain polemic with readers. However, as the President of the ADRA, Anne-Laure Amilhat-Szary, points out in the magazine L'Alpe, "the multilanguage solution [...] offers an original platform for intellectual and cultural diversity on alpine issues by enabling every language spoken in European mountain areas, and by its researchers, to be present (translation)" ${ }^{1}$. To remain coherent with its new editorial policy and to facilitate referencing, the journal has recently given precedence to its English name, thus becoming the Journal of Alpine research | Revue de géographie alpine. It is now integrated in the following indexing systems: Library of Congress, revues.org, EDS and AtoZ of EBSCO, 360 Core of Serials Solutions, SFX and Primo Central of Ex Libris, and the Summon service of ProQuest. The journal is also referenced by the AERES, the Web of Science, Scopus and the DOAJ.

6 This new linguistic strategy, aimed at maximum sharing of the porting of numbers and proposals of articles at the scale of the Alpine Arc, is already bearing fruit. Eloquent proof of this is the "young researcher" competition, which has attracted articles in German, Italian, French and English. Six of these articles have been selected for publication, the best of which has also received a prize of 500 euros. The choice was made by researchers on the enlarged editorial committee of the Journal based on several criteria. First, there is the innovative character of the topic covered by the article and, most importantly, the status given to mountain areas within this topic. Reviewers also attempted to assess the potential for extending the approach to other cases (theorization) and the nomothetic potential (the capacity for generalization) of the article. Qualities relating to the form of the article (drafting and illustrations) were also evaluated.

7 The articles in this special issue provide ample evidence that alpine research is alive and well, diversified in the topics it deals with, and well organized around strong international networks, enabling the sharing of results through numerous partnerships. Our journal is the product of these scientific and human synergies at the scale of the Alpine Arc, and it is hoped that this issue will help open up paths for debate and collaborative arrangements in alpine research in the coming years.

8 To conclude, what can we wish the Journal of Alpine Research for the next one hundred years? Perhaps, quite simply, to function smoothly with a dynamic editorial team that 
is not afraid to take up scientific and disciplinary challenges, a team that is curious and open-minded, capable of showing proof of commitment, and a team that does not forget its first love: the mountains. We can also hope that there are even more researchers wanting to share their findings and their enthusiasm for the subject. Finally, and most importantly, we hope that you, the readers, continue to find pleasure and interest in discovering the articles brought to you in the Journal, whatever format they may be in!

\section{NOTES}

1. AMILHAT-SZARY A.-L ., 2013, «Grenoble accueille désormais le Journal of Alpine Research : la Revue de Géographie Alpine est morte, vive la Revue de Géographie Alpine ! », in l'Alpe n63, Glénat, p. 94.

\section{AUTEUR}

\section{DOMINIQUE BAUD}

Maître de conférence en géographie et géomatique, Laboratoire PACTE, UMR 5194 CNRS / Institut de Géographie Alpine / Université Grenoble Alpes 